\title{
SECTIONS 9 AND 10 OF THE RIVERS AND HARBORS ACT OF 1899: THE EROSION OF ADMINISTRATIVE CONTROL BY ENVIRONMENTAL SUITS
}

Sections 9 and 10 of the Rivers and Harbors Act of $1899^{1}$ grant the United States Army Corps of Engineers (Corps) control over obstructions to navigable waters. ${ }^{2}$ Section 9 outlines the requirements for ap-

1. 33 U.S.C. $\$ \S 401,403$ (1976).

2. The Rivers and Harbors Act of 1899 contains several sections pertaining to Corps authority over navigation. Obstructions other than those listed in sections 9 and 10 are placed under Corps control in other parts of the Act.

Section 11 of the 1899 Act, $i d . \S 404$, einpowers the Secretary of the Army to authorize harbor lines beyond which no structures may extend. Section 10 permits are now requircd for structures within the harborlines, although they were not necessary until 1970. 42 Fed. Reg. 37,161 (1977).

Section 12, 33 U.S.C. $\$ 406$ (1976), makes violations of sections 9, 10, and 11 criminal acts and imposes fines up to $\$ 2500$ or inprisonment for up to one year or both. This provision also allows for the removal or abatement of offending structures. Until recently violators were rarely prosecuted, and even now the Corps and the Justice Department are reluctant to prosecute. House Comm. on Government Operations, InCreasing Protection for OUR Waters, Wetlands, and Shorelines: The Corps of Engineers, H.R. Rep. No. 1323, 92d Cong., 2d Sess. 16-26 (1972).

Section 13 (commonly known as "The Refuse Act"), 33 U.S.C. $\S 407$ (1976), prohibits the discharge of "any refuse matter of any kind or description" into navigable waters. The Corps of Engineers, the Congress, and the Nixon administration all conceived the idea of prohibiting water pollution under this section at roughly the same time. The House Government Operations Committee first raised the issue in March of 1970 . HOUSE COMM. ON Government Operations, Our Waters and Wetlands: How the Corps of Engineers Can Help Prevent Their Destruction and Pollution, H.R. Rep. No. 917, 91 st Cong., 2d Sess. (1970). President Nixon established a formal section 13 permit program on December 23, 1970. Exec. Order No. 11,574, 3 C.F.R. 575 (1970). The Corps alinost simultaneously pronulgated the regulations for the program. 33 C.F.R. $\S 209.131$ (1972). These actions were endorsed by inany environinental groups. Rodgers, Industrial Water Pollution and the Refuse Act: A Second Chance for Water Quality, 119 U. PA. L. REv. 761, 767-69 (1971).

At least one commentator saw the danger of employing a 70-year-old provision to do the work of a comprehensive water pollution control prograin. See Comment, Discharging New Wine into Old Wineskins: The Metamorphosis of the Rivers and Harbors Act of 1899, 33 U. PITT. L. REv. 483,485 (1972). This use of section 13 proved to be a problen, and the program was suspended for one year following the case of Kalur v. Resor, 335 F. Supp. 1 (D.D.C. 1971), in which the permit program was found to violate the terms of the National Environmental Policy Act of 1969, 42 U.S.C. $\S \S 4321-4361$ (1976). Congress subsequently passed the 1972 Amendments to the Federal Water Pollution Control Act, Pub. L. No. 92-500, § 402, 86 Stat. 816 (codified at 33 U.S.C. $\S 1342$ (1976)), which prohibited the Corps from issuing further section 13 permits. The new Act gave the Environmental Protection Agency sole authority to issue water pollution discharge permits. Section 13 remains viable for criminal enforcenent, but only when no permit is issued for the discharge. 42 Fed. Reg. 37,123 (1977); see House COMm. ON GOVERNMENT OpERATIONS, 
proval to construct dams, dikes, bridges, or causeways in a navigable waterway. ${ }^{3}$ This provision apportions legislative approval authority between the state legislatures and the United States Congress: a state legislature has authority over those structures in waterways that are navigable only within its boundaries, while Congress possesses approval power for those structures in waterways that are navigable in more than one state. ${ }^{4}$ In both cases, the Corps must consent to the construction of the project.

Section 10 gives the Corps exclusive authority to approve construction of smaller structures, such as wharves, booms, and bulkheads, as well as to approve dredging and filling operations. ${ }^{5}$ This section also bans all obstructions to "the navigable capacity of any of the waters of

ENForCement of THE Refuse ACT of 1899, H.R. Rep. No. 1333, 92d Cong., 2d Sess. 50-51 (1972). See also United States v. Pennsylvania Indus. Chem. Corp., 411 U.S. 655, 662-63 (1973).

Section 14, 33 U.S.C. $\$ 408$ (1976), provides for the preservation against seizure or damage of all structures built by the United States in navigable waters.

Section 15 , id. $\$ 409$, prohibits the use of floating or sunken vessels, or floating logs and timber, to obstruct navigable waters.

Section 16, id. $\S 411$, establishes criminal penalties cousisting of one-year imprisonment and up to a $\$ 2500$ fine for violations of sections 13,14 , and 15 .

3. Section 9 provides:

It shall not be lawful to construct or commence the construction of any bridge, dam, dike, or causeway over or in any port, roadstead, haven, harbor, canal, navigable river, or other navigable water of the United States until the consent of Congress to the building of such structures shall have been obtained and until the plan for the saine shall have been submitted to be approved by the Chief of Engineers and by the Secretary of the Army: Provided, That such structures nay be built under authority of the legislature of a State across rivers and other waterways the navigable portion of which lie wholly within the limits of a single State, provided the location and plans thereof are submitted to and approved by the Chief of Engineers and by the Secretary of the Army before construction is commenced. And provided further, That when plans for any bridge or other structure have been approved by the Chief of Engineers and by the Secretary of the Army, it shall not be lawful to deviate from such plans either before or after completion of the structure unless the modification of said plans has previously been submitted to and received the approval of the Chief of Engineers and the Secretary of the Army.

Id. $\$ 401$. Bridges are now under the approval authority of the Secretary of Transportation. 49 U.S.C. $\$ 1655(\mathrm{~g})(6)(\mathrm{A})$ (1976). The Department of Energy holds the delegated congressional approval power for hydroelectric dams and projects. 42 U.S.C. $\$ \$ 7151$ (b), 7172 (Supp. I 1977).

4. 33 U.S.C. $\$ 401$ (1976).

5. Section 10 provides:

The creation of any obstruction not affirmatively authorized by Congress, to the navigable capacity of any of the waters of the United States is hereby prohibited; and it shall not be lawful to build or commence the building of any wharf, pier, dolphin, booin, weir, breakwater, bulkhead, jetty, or other structures in any port, roadstead, haven, harbor, canal, navigable water, or other water of the United States, outside established harbor lines, or where harbor lines have been established, except on plans recommended by the Chief of Engineers and authorized by the Secretary of War; and it shall not be lawful to excavate or fill, or in any manner to alter or modify the course, location, condition, or capacity, of any port, roadstead, haven, harbor, canal, lake, harbor or refuge, or inclosure the limits of any breakwater, or of the channel of any navigable water of the United States, unless the work has been recommended by the Chief of Engineers and authorized by the Secretary of War prior to beginning the same.

Id. § 403 . 
the United States,"6 unless the obstruction is affirmatively authorized by Congress. Sections 9 and 10 together attempt to protect the strong federal imterest im open and unfettered waterborne commerce between the states, while allowing for the accommodation of local interests.

The slow assertion of federal control over internal waters culminated in the 1899 Act. $^{7}$ Prior to 1890 , private obstructions to navigable waterways were constructed without regard to their effect on navigation. Many of these structures carried the imprimaturs of local legislatures. The Supreme Court repeatedly held that the Umited States could not force the removal of these obstructions without an act of Congress asserting federal control over the waterways. ${ }^{8}$ In response to these decisions, Congress passed the Rivers and Harbors Act of 1890,9 establishing the requisite federal control. Although the subsequent Rivers and Harbors Act of 1899 purported merely to codify earlier acts, ${ }^{10}$ including the 1890 Act, it actually constituted a wholly different division of control between the Corps, the state legislatures, and Congress. ${ }^{11}$

Lacking an accurate legislative history for sections 9 and 10, the courts and the Corps have had to fashion their own interpretations of the Act. The interpretative problems center on the meaning of the terms used in the Act to describe the types of waterways covered and the various structures for which approval must be obtained. These terms outline the limits of Corps administrative power under sections 9 and 10. Accordingly, the Corps has consistently construed the terms to favor a broad exercise of its own power. ${ }^{12}$ Until the early 1960s the courts' interpretation of the two sections was similar to the Corps' view of its own power. ${ }^{13}$ The courts extended the scope of the Act and left the broadened power in the hands of the Corps. Since that time, however, the cases have narrowed the approval power of the Corps.

The advent of environinental legislation in the late 1960s forced the Corps to incorporate a review of the environmental impact of projects into its approval procedures under the Rivers and Harbors

6. Id. The Secretary of the Army's section 10 authority now extends to structures on the Outer Continental Shelf. 43 U.S.C. \& 1333(f) (1976).

7. 33 U.S.C. $\$ \S 401,403,404,406-409,411-415,418$ (1976).

8. See text accoinpanying note 34 infra. This accommodation of state intercst in obstructions to navigable waters is a classic example of the views of the federal commerce power prevailing during that era.

9. Ch. 907,26 Stat. 426.

10. See text accoinpanying notes 54-57 infra.

11. See text accoinpanying notes 58-60 infra.

12. See text accoinpanying notes 83-88 infra.

13. See notes $150-55$ infra and accompanying text. 
Act. ${ }^{14}$ This review imposed pollution controls on projects not previously affected by ecological considerations. At the same time, however, public interest organizations began exploiting the vague terms used in sections 9 and 10 as a means of attaining their own environmental objectives. They sought to block construction of certain waterway-related projects by claiming improprieties in the approval procedures. These suits typically alleged that the project had been approved by the Corps under the wrong section of the 1899 Act. ${ }^{15}$ Although these suits inay have been beneficial in halting undesirable projects, they have also served to weaken the statutory basis under which the Corps conducts its own environmental and navigational review. In the long run this litigation may hamper the Corps' ability to insure environmental protection in many smaller yet potentially damaging projects. ${ }^{16}$ This impairment of environmental review would result from requiring congressional approval for a greater number of construction projects because Congress need not follow environmental standards. ${ }^{17}$ Furthermore, when faced with the expense and difficulty of obtaining congressional approval for small projects, ${ }^{18}$ the proponents of the projects may well ignore all legislative and administrative approval requireinents. ${ }^{19}$ If the proponents attempt to evade all approval procedures, there would be no environmental review of the project at all.

The optimal solution to these interpretive problems of sections 9 and 10 is to redraft the Rivers and Harbors Act to define precisely the Corps' administrative powers. A redraft would also reflect modern notions of the federal and state interests in navigable waterways: the federal interest is primarily in free commerce on navigable waters, and the state interest is principally health and safety. ${ }^{20}$

This Comment will examine the cases preceding the 1899 Act, the passage of the 1899 Act, and other legislative history. It will then discuss the environmental use of sections 9 and 10-both the Corps' review mandated by Congress and the environmental groups' use of the Act's ambiguities in suits to block construction of waterway-related projects. These ambiguities will be analyzed in turn, first with regard

14. See notes 61-78 infra and accompanying text.

15. See notes 89-102, 1111-17 infra and accompanying text.

16. This environmental review and enforcement is particularly vital to regions such as Florida and the Gulf Coast, where a popular means of land development consists of dredging and filling marshes, lagoons, and bays - a practice generally regarded as environmentally unsound. See text accompanying notes $71,73-78$ infra.

17. See note 87 infra.

18. See notes 134,145 infra.

19. See note 148 infra.

20. See note 25 infra and accompanying text and note 177 infra. 
to section 9 and then with regard to section 10. The Comment will conclude with a proposed model redraft of sections 9 and 10, designed to remove the interpretive difficulties plaguing the Army Corps of Engimeers' environmental and navigational review.

\section{The Legislative History of Sections 9 and 10}

Sections 9 and 10 of the Rivers and Harbors Act of $1899^{21}$ reflect an 1880s view of the federal commerce power. Its broad assertion of federal power, its recogmition of limited state power, and its annbiguous delegation of administrative power all have their roots in the acts, cases, and theories of commerce and navigation prior to 1899 . The form and content of the 1899 Act cannot be understood without an initial examination of the case law and legislation in force prior to the passage of the Act.

\section{A. The Cases Preceding the 1899 Act.}

Gibbons v. Ogden ${ }^{22}$ placed control over navigation squarely within Congress' commerce power: "All America understands, and has uniformly understood, the word 'commerce,' to coinprehend navigation." ${ }^{23}$ Five years later, the Court qualified this broad assertion in Wilson v. Black Bird Creek Marsh Co., ${ }^{24}$ the first Supreme Court case concerning an obstruction to navigable waters. In Black Bird Creek the Court recognized that a legitiniate local health concern could justify a state's regulation of commerce, even in the face of a strong federal interest in navigation. ${ }^{25}$ The 1899 Act apparently attempted to accoininodate these interests. ${ }^{26}$

With the rapid growth of railroads after $1835^{27}$ and the parallel developinent of steamboat travel on the inland rivers and lakes, ${ }^{28}$ the problem of manmade obstructions to navigation increased. The federal government had begun a program of river intproveinents with particular emphasis on the construction of locks, canals, and dams. These improveinents frequently were rendered useless by the construction of

21. 33 U.S.C. $\$ \S 401,403$ (1976).

22. 22 U.S. (9 Wheat.) 1 (1824).

23. $I d$. at 190.

24. 27 U.S. (2 Pet.) 245 (1829).

25. Id. at 250 . Today this health concern would be a factor considered by the Corps during its environmental review of the project. 42 U.S.C. $\S 4332$ (1976).

26. See notes $47-49$ infra and accompanying text.

27. See, e.g., W. Clark, Railroads and Rivers (1939); E. Hungerford, The Story of THE BALTIMORE AND OHIO RAILROAD (1928).

28. See, e.g., L. Hunter, Steamboats ON Western Rivers (1949). 
railroad trestles, private dams, and floatimg booms. ${ }^{29}$ Often, these obstructions were authorized by state legislative acts. ${ }^{30}$

In Pennsylvania v. Wheeling \& Belmont Bridge Co.,$^{31}$ the Supreme Court suggested that a common law action for nuisance could result im a court-ordered abatement of the structure, either by removal or alteration. ${ }^{32}$ Later courts, however, did not follow this suggestion. When the United States and private parties sought to remove these state-approved structures, the courts consistently ruled that in the absence of a federal law prohibitimg obstructions to navigable waters, no remedy could be granted..$^{33}$ According to the Supreme Court,

[t] he power of Congress to pass laws for the regulation of the navigation of public rivers, and to prevent any and all obstructions therein, is not questioned. But until it does pass soine such law, there is no common law of the United States which prohibits obstructions and nuisances in navigable rivers. . . . There must be a direct statute of the United States in order to bring within the scope of its laws, as

29. The federal government recognized the anomaly of authorizing large federal expenditures for the improvement of navigation and concurrently adopting a laissez-faire policy toward obstructions to that navigation:

From 1816 to 1890 immense amounts of public moneys were appropriated for and applied to the improvements of rivers and liarbors, and it frequently happened that while the public was expending money to increase the facilities of navigation of a river some interested party was serving his or its private interest by placing obstructive bridges or other impediments in the way.

20 OP. ATT'Y GEN. 488, 489 (1892).

30. This freewlieeling policy toward private obstructions to navigation certainly existed in state legislatures:

We liave liad a great many cases in the South where we have undertaken to make improvements in rivers, and have again and again made appropriations, provided that the railroads would put draws into their bridges which had been authorized by the State or had been built with authority, one or the other, and they liave defied us, and it has been utterly impossible to get along.

21 CoNG. ReC. 8602 (1890) (remarks of Sen. Frye) (emphasis added).

31. 54 U.S. (13 How.) 518 (1851).

32. Id. at 564 .

33. See Willamette Iron Bridge Co. v. Hatch, 125 U.S. 1 (1888) (counsel for party opposing this bridge was United States Senator J.N. Dolph, sponsor of the 1890 Act). See also Cardwell v. American Bridge Co., 113 U.S. 205, 208 (1885) (bridge obstructing the American River in California held to be properly authorized by state legislature in the absence of contrary congressional action); Escanaba v. Chicago, 107 U.S. 678, 687 (1882) (Chicago ordinance requiring the closing of drawbridges during rush hour held not to be an obstruction to navigation in hight of no congressional action on the subject); Pound v. Turck, 95 U.S. 459, $462-64$ (1877) (absent conflictimg congressional action, a state-authorized dam in the Chippewa River is not an obstruction to navigation); Gilman v. Philadelphia, 70 U.S. (3 Wall.) 713 (1865) (bridge spanning Schuykill River is not an impediment to navigation absent contrary congressional action); United States v. Beef Slough Mfg., Booming, Log Driving \& Transp. Co., 24 F. Cas. 1064, 1064 (C.C.W.D. Wis. 1879) (No. 14,559) (the United States is unable to remove booms blocking the Chippewa River without enabling legislation by Congress); United States v. Duluth, 25 F. Cas. 923, 924 (C.C.D. Minn. 1871) (No. 15,001) (the United States nuay enjom private activities in Lake Superior that defeat the purpose of Congressionally authorized navigational improvements). This line of cases epitomizes the Supreme Court's view of the federal cominerce power prevailing at that time. 
administered by the courts of law and equity, obstructions and nuisances in navigable streams within the State. ${ }^{34}$

\section{B. The Legislation Preceding the 1899 Act.}

In response to the courts' requirement of congressional action to override state obstruction of navigable waters, Congress began to pass a series of statutes asserting its power over these waterways. ${ }^{35}$ In 1884

34. Willamette Iron Bridge Co. v. Hatch, 125 U.S. 1, 8 (1888).

35. Congress incorporated into its legislation the judicial interpretation of "navigable waters." "Navigability" is a term of art shaped by 150 years of Supreme Court decisions. Three types of cases have defined the term: admiralty cases, cases determining the ownership of riverbeds, and commerce clause cases dealing principally with navigation and hydroelectric power generation. The admiralty cases use the terin to define the reach of federal court admiralty jurisdiction and have given it a restrictive interpretation. See Executive Jet Aviation, Inc. v. City of Cleveland, 409 U.S. 249 (1972). The property rights cases use the tern to define waterways subject to federal servitudes. See Vaughn v. Vermilion Corp., 100 S. Ct. 399 (1979); Kaiser Aetna v. United States, 100 S. Ct. 383 (1979). The commercial cases have used the terin more expansively, although they have borrowed heavily from the admiralty and property rights cases.

Until 1851 the test for navigable waters was whether the waterway was tidal. The early cases applying this criterion were admiralty cases; they simply referred to the "ebb and flow" test used by the courts in Great Britain as of 1783. See Steamboat Orleans v. Phoebus, 36 U.S. (11 Pet.) 175, 183 (1837); Peyraux v. Howard, 32 U.S. (7 Pet.) 324, 342-44 (1833); The Thomas Jefferson, 23 U.S. (10 Wheat.) 428,429 (1825). These cases determined that certam imland waterways-the Mississippi, the Great Lakes, the Hudson - were not subject to the admiralty jurisdiction of the federal courts.

Subsequently, in Waring v. Clarke, 46 U.S. (5 How.) 441 (1847), the Supreme Court rejected the practice of relying on British notions of admiralty jurisdiction. The Court found that even in colonial times the American admiralty courts had a greater jurisdiction than British courts. Id. at 454-58. Nonethcless, while recognizing these differences, the Court reafirmed the test of "cbb and flow of the tide" for determining navigable waters. Id. at 464.

Four years later, Chief Justice Taney established a fully American test for navigable waters in Propeller Genesse Chief v. Fitzhugh, 53 U.S. (12 How.) 443 (1851). The case concerned a collision on Lake Ontario. In finding admiralty jurisdiction, the Court rejected the "ebb and flow" test in favor of "navigability in fact." Id. at 457 . Chief Justice Taney reasoned that the only waters in England that were navigable were indeed tidal. In the United States, on the other hand, the geographical variations and the greater use of the steamboat separated the concepts of "ebb and flow" and navigability. Id. at 454-57. Henceforth, the test was whether the waterway was susceptible to or could actually support commerce and navigation. The classic fornulation of the test came several years later: "If it be capable in its natural state of being used for purposes of cominerce, no matter in what mode the commerce nay be conducted, it [the waterway] is navigable in fact, and becoines in law a public river or highway." The Montello, 87 U.S. (20 Wall.) 430, $441-42$ (1874). In Montello, the river was used for early fur trading and was thus considered navigable, even though in its natural state it had many rapids. During the interim between the Fitzhugh and Montello decisions, the Supreme Court had moved away from an admiralty approach and spoke instead of Congress' commerce clause powers. See, e.g., The Damiel Ball, 77 U.S. (10 Wall.) 557, 563-64 (1870). The Court found the requisite commerce if the goods being carried were inoving interstate, even if the steamer was not. Id. at 565. Finally, in Exparte Boyer, 109 U.S. 629 (1883), the Court extended the test to include wholly inanmade waterways. Id. at 632.

In Economy Light \& Power Co. v. United States, 256 U.S. 113 (1921), the Court further liberalized the navigable waters concept by holding that once a waterway supports interstate coinmerce, it is always subject to federal control. Such control can then be waived only by an act of 


\section{Congress directed the Secretary of War to submit to the next Congress}

Congress, regardless of whether the waterway is subsequently obstructed, dammed, dry, or similarly nonnavigable in fact. $I d$. at 124.

In United States v. Appalachian Elec. Power Co., 311 U.S. 377 (1940), the Court completed the scheme by holding that waterways that do not support commerce, but are susceptible to navigation and commerce by means of reasonable innrovement, are navigable waters of the United States: "A waterway, otherwise suitable for navigation, is not barred from that classification merely because artificial aids must make the highway suitable for use before commercial navigation may be undertaken." Id. at 407.

Any type of interstate commerce will create navigability. Logs floating downstream from the place of foresting may be sufficient. St. Anthony Falls Water Power Co. v. St. Paul Water Comm'n, 168 U.S. 349, 359 (1897); United States v. Mississippi \& Rum River Boom Co., 3 F. 548, 550-51 (C.C.D. Minn. 1880). In theory, even rum-running, the smuggling of illegal whiskey into the United States, might vest the most remote and shallow inlets and creeks with a federal imterest. Also, pleasure boating may indicate that a waterway is susceptible to commercial use. See, e.g., United States v. Underwood, 344 F. Supp. 486, 490-91 (M.D. Fla. 1972); United States v. Crow, Pope \& Land Enterprises, 340 F. Supp. 25,34 (N.D. Ga. 1972).

Until recently the physical jurisdiction of the Corps extended only as far as the navigable waterway extended. That is, Corps control ended at the mean high-water mark, or where the waterway became clearly nonnavigable. The courts, however, have broadened this interpretation in recent commerce clause decisions relying on an 1899 Supreme Court decision, United States v. Rio Grande Dam \& Irrigation Co., 174 U.S. 690 (1899). In that case the Court found that a dam located in a nonnavigable portion of the river would affect the navigability of the rest of the river through massive water diversions. The opinion suggested that in such cases federal jurisdiction could run beyond conventional boundaries. $I d$. at 708,709 . Over 65 years later, the power of the Corps was extended beyond navigable waters when onshore activity had an intpact on navigation. (The runoff of fill material is one example of an onshore activity affecting navigation.) See United States v. Joseph G. Moretti, Inc., 526 F.2d 1306 (5th Cir. 1976) (Moretti II); Weiszmann v. District Eng'r, United States Army Corps of Eng'rs, 526 F.2d 1302 (5th Cir. 1976); Umited States v. Sexton Cove Estates, Inc., 526 F.2d 1293, 1298 (5th Cir. 1976); United States v. Perma Paving Co., 332 F.2d 754 (2d Cir. 1964); Sierra Club v. Leshie Salt, 412 F. Supp. 1096, 1102 (N.D. Cal. 1976). See also 33 C.F.R. § 329 (1979); 42 Fed. Reg. 37,127-32 (1977).

The concept of navigable waters also applies to riparian rights. When a waterway is found to be navigable, a federal servitude for navigation is imposed on the riparian owners and the owners of the riverbed. See United States v. Rands, 389 U.S. 121 (1967); United States v. Chicago, Mil., St. P. \& Pac. R.R., 312 U.S. 592 (1941). Usually there is no compensation for the imposition on this servitude. The Supreme Court recently addressed the issue of compensation to the owners of private waterways that have becoine navigable and thus subject to a federal navigational servitude. Vauglin v. Vermilion Corp., 100 S. Ct. 399 (1979) (per curiam); Kaiser Aetna y. United States, 100 S. Ct. 383 (1979). The Vaughn and Kaiser Aetna cases concerned Corps' efforts to control structures both in a private fishpond recently opened to the ocean and in manmade canals. Both waterways were on private property and were formerly normavigable. The Court held that before exercising a federal navigational servitude, the federal goverument must provide compensation, as in other emment domain actions. $100 \mathrm{~S}$. Ct. at $401 ; 100 \mathrm{~S}$. Ct. at 393 . This ruling obviously cuts back on the scope of the Corps' environmental review in areas such as Florida, where manmade canals are popular components of land developments.

The dissents in Vaughn and Kaiser Aetna offered an alternative test for navigability. The minority would exhume the "ebb and flow" test for all tidal waterways, regardless of whether the waterway was manmade. $100 \mathrm{~S}$. Ct. at 402 (Blackmun, J., dissenting); $100 \mathrm{~S}$. Ct. at 394 (Blacknuun, J., dissenting). From an environmental standpoint, the "ebb and flow" test is initially appealing. It would cover those situations, such as the private fishpond newly linked to the ocean or 
a list of all manmade obstructions to navigable waters. ${ }^{36}$ The same Act also empowered the Secretary of War to order the installation of buoys, markers, and bulkheads where necessary to alleviate difficulty im passing under low bridges. ${ }^{37}$ Congress requested another survey of obstructions in 1886.38 Finally, in 1888, Congress authorized the Secretary to require the alteration of bridges obstructing navigation. ${ }^{39}$

The Rivers and Harbors Act of $1890^{40}$ ended this piecemeal approach. In broad, sweeping language, the Act stated that "[t]he creation of any obstruction, not affirmatively authorized by law, to the navigable capacity of any waters, in respect of which the United States has jurisdiction, is hereby prohibited."41 The Act also contamed other essential elements that were later incorporated into the 1899 Act: criminal penalties for refusing to alter bridges; 42 prohibitions on the dumping of refuse, ${ }^{43}$ and approval requirements for the construction of "any wharf, pier, dolphin, boom, dam, weir, breakwater, bulkhead, jetty, or structure of any kind." 44 Furthermore, the 1890 Act vested all ap-

the manmade canals, that would be effectively excluded from the Corps' control under the majority's finding.

Implicit in the dissents' reasoning, however, is the notion that the Appalachian Power formulation of the test of navigability is no longer useful in defining the limits of navigable waters. In Vaughn and Kaiser Aetna, application of the Appalachian Power and "ebb and flow" tests would lead to the same conclusion - that the fishpond and manmade canals were navigable waters. Thus, Justice Blackmun could have reached the result he desired without resorting to the "ebb and fiow" test. His use of the "ebb and flow" test in these circumstances may therefore imply that for some unstated reason the Appalachian Power test is unworkable. This impleation raises the question of what will be the new test for inland waters, to which the proposed "ebb and flow" test would not extend. From an environmental standpoint, the dissent should have adhered to the Appalachian Power test and avoided casting doubt over the usefulness of the broad Appalachian Power test for inland, nontidal waters.

For a discussion of the practical impact of federal navigational servitudes on riparian propenty owners, see Johnson, Enforcing the Federal Water Resource Servitude on Submerged and Riparian Lands, 1977 DUKE L.J. 347.

36. Rivers and Harbors Act of 1884, ch. 229, § 9, 23 Stat. 154.

37. Id. $\S 8$.

38. Rivers and Harbors Act of 1886, cl. 929, $\S 4,24$ Stat. 330.

39. Rivers and Harbors Act of 1888, ch. 860, $\S 9,25$ Stat. 424.

40. Ch. 907,26 Stat. 426.

41. Id. $\S 10$.

Clearly, Congress was meeting the objectious of the Supreme Court. In the Senate debate on the bill, Senator Edmunds from Vermont recognized that "the assertion of this power must be made by Congress, and that until it does inake it the obstruction of a stream is no violation of any law of Congress and not of the common law . . . " 21 Cong. Rec. 8605 (1890) (remarks of Sen. Edmunds). This remark followed a discussion of Willamette Iron Bridge Co. v. Hatch, 125 U.S. 1 (1888), and Escanaba v. Chicago, 107 U.S. 678 (1882), both of which stated this need for congressional action. 21 CoNG. REC. 8604-05 (1890) (reinarks of Seu. Dolph and Sen. Edmunds).

42. Rivers and Harbors Act of 1890, ch. 907, \& 10, 26 Stat. 426.

43. Id. $\S 6$.

44. Id. $\$ 7$. 
proval power in the Secretary of War. ${ }^{45}$ It exeinpted from War Departinent approval those bridges located in water navigable only in one state. ${ }^{46}$

Despite these legislative efforts, both the language of the Act and Congress' understanding of the state legislative approval powers were unclear. ${ }^{47}$ The Act seemed to suggest that state legislative approval of a bridge alone would suffice when the waterway in question was navigable wholly within one state. Given the states' hostility to unimpeded navigation prior to 1890,48 this provision imphed that navigation and commerce on an intrastate river were viewed as less important than similar navigation and commerce on an interstate waterway. Thus, a steamboat and its cargo could travel freely on the Mississippi River but would encounter all manner of state-approved obstructions once it ventured onto a separate intrastate waterway. Theoretically, the purpose of this delegation of approval power to the states was to accommodate local interests. It is unclear, however, why the local interests in an intrastate waterway were elevated above those in an interstate waterway, when in reakty both the federal interest in commerce and the states' interest in local affairs were constant, regardless of the character of the waterway. In the final analysis, this may have been simply a political coinpromise by Congress. The 1899 Act not only carried over this apparent accommodation of state interests, but substantially expanded it as well. 49

45. Id. Senator Gray determined that the Act

wisely commits this [approval] matter to the Secretary of War, to a Department that controls the engineering affairs of the United States and the engineering intelligence of the United States, and there is no objection that that Department should have the authority granted in this section of the bill. It is an administrative duty that is imposed ...

21 CoNG. ReC. 8604 (1890) (remarks of Sen. Gray) (einphasis added). The sponsor of the bill, Senator Dolph, felt that this delegation of power "would be a very good thing and relieve Congress from a great deal of labor on this question [of approving obstructions]." Id. 8605 . He did, however, have doubts about the constitutionality of the Secretary's power to order alteration or removal of an obstruction; he saw that as a judicial function. Id.

46. Rivers and Harbors Act of 1890 , ch. $907, \S 7,26$ Stat. 454. The Act also provided a grandfather clause for those bridges already approved by state legislatures. Id.

47. Senator Dolph, the sponsor, stated that the

bill provides that any association or corporation may obtain pernnission to construct a

bridge over a navigable streain (I am not certain whether it is limited to streams entirely within a State) by making application to the Secretary of War and submitting the plans and drawings to the Secretary for his approval.

21 CoNG. REC. 8605 (1890) (reinarks of Sen. Dolph) (emphasis added).

48. See note 30 supra.

49. The 1890 Act allowed states to approve bridges. Ch. $907, \S 7,26$ Stat. 454 . The 1899 Act expanded that power to include dams, dikes, and causeways as well. Ch. $425, \S 9,30$ Stat. 1151 (codified at 33 U.S.C. $\$ 401$ (1976)). 
C. The Passage of the 1899 Act.

The 1890 Act thus set the framework for the enactment of sections 9 and 10 nine years later. Because the 1890 statute was unclear, the courts contmued to limit congressional powers over obstructions in navigable waters. The courts were particularly concerned with the ability of Congress to delegate its approval authority to the Secretary of War, ${ }^{50}$ viewing this as an unconstitutional delegation of legislative functions. ${ }^{51}$ In response, Congress asked the Secretary of War to codify existing laws governing obstructions to navigable waterways. ${ }^{52}$ The Secretary complied and sent the proposed codification to Congress in February of 1897.53

This codification lay dormant until 1899, when it was hurriedly attached as an annendment to that year's Rivers and Harbors Appropriations bill..$^{54}$ During the brief Senate consideration of the bill, the sponsors claimed that it mcorporated no significant changes of earher law. ${ }^{55}$ The Senate therefore adopted the aunendments without having heard them read aloud. ${ }^{56}$ The conference report stated, "The Bill now agreed upon and presented also includes a codification of existing laws pertaining to rivers and harbors, though containing no essential changes in the existing law." 57 This statement, however, was incorrect. The 1899 Act was no mere codification; instead, it reapportioned administrative and legislative authority over obstructions to navigation.

The 1899 Act contained three major changes from the 1890 Act. First, the 1890 Act did not define Corps power according to the type of

50. See United States v. Rider, 50 F. 406, 408-10 (S.D. Ohio 1892), rev'd, 178 U.S. 251 (1900); United States v. Keokuk \& Hamilton Bridge Co., 45 F. 178, 182 (S.D. Iowa 1891).

51. The United States Attorney General opined that no "general legislation confer[s] the power of approval upon the Secretary of War over such waters." 20 OP. ATT'Y GEN. 488, 492 (1892).

52. Rivers and Harbors Act of 1896, ch. 314, § 2, 29 Stat. 202.

53. H.R. Doc. No. 293, 54th Cong., 2d Sess. 1-2 (1897).

54. Rivers and Harbors Act of 1899 , ch. $425,8 \S 9-20,30$ Stat. 1151 (codified at 33 U.S.C. $\S \S 401,403,404,406-409,411-415,418$ (1976)).

55. This debate occurrcd when the Senate was trying to decide whether the amendment should be read before being voted upon:

Senator Chandler: "I wish to ask the Senator whether there is any change inade in the existing laws by the amendments?"

Senator Frye [the sponsor]: "Very slight changes to remove ambiguities. . . ." ....

Senator Pettigrew: "I do not like to object, but I think this is a dangerous precedent. It seems to nue we are enacting an entire revision of these laws."

Senator Frye: "Oh no. There are not ten words changed in the entire thirteen sections." 32 CONG. REC. 2297 (1899) (einphasis added).

56. $I d$.

57. Id. 2923 (statement of conference committee). 
obstruction involved; the 1899 Act did. ${ }^{58}$ Next, the 1890 Act did not require congressional approval for any structure, whereas section 9 of the 1899 Act required such approval for dikes, dains, bridges, or causeways. ${ }^{59}$ Finally, the 1890 Act confined state legislative approval to bridges over intrastate waterways; the 1899 Act expanded this power to include dams, dikes, and causeways as well. ${ }^{60}$

Overall, the 1899 Act narrowed the broad, exclusive power of the Corps. It made approval for certain structures considerably more diffcult to obtain by requiring congressional authorization. With this narrowing of Corps power, the 1899 Act would probably not be attacked as unconstitutionally delegating legislative power. Those structures inost likely to obstruct navigation - and thereby to produce litigationnow needed some form of legislative approval. In this way the 1899 Act accommodated the political forces and legal theories that undermined the 1890 Act.

Because the 1899 Act limited the administrative power originally allocated to the Corps, the assertion that the Act was a inere codification was patently false. Congress was deceived, and any attempt to determine the legislative intent behind the 1899 Act thus becomes complex. It would be misleading to make any cross reference to the 1890 Act, for the division of powers under the earlier act was far different froin that of the later act. An understanding of Congress' "intent" in passing the 1899 Act, therefore, requires study not only of the 1890 Act, but also of the judicial rulings preceding both acts and the reasons for the changes effected in the 1899 Act.

\section{The Environmental Use of Sections 9 and 10}

\section{A. Statutorily Required Environmental Review.}

Although sections 9 and 10 address only navigation, the Corps inust consider the environmental effects of a proposed structure or activity, as well as the navigational effects, before issuing permits under either section. This expanded investigation is the result of a series of related federal statutes and congressional mandates that seek to institutionalize conservationist concerns.

The Fish and Wildlife Coordination Act of 1934 and its 1958 amendments ${ }^{61}$ require that all federal agencies consult with the Depart-

58. 33 U.S.C. $\$ \S 401,403$ (1976).

59. $I d . \S 401$.

60. Id.

61. 16 U.S.C. $\$ \S 661-666$ (1976) (originally enacted as Pub. L. No. 73-121, \$§ 1-6, 48 Stat. 401 (1934), and anended by Act of Aug. 12, 1958, Pub. L. No. 85-624, § 2, 72 Stat. 563). 
ment of the Interior's Fish and Wildlife Service to determine the impact of governmental projects on fish and wildlife. ${ }^{62}$ In 1970 Congress passed tlie National Environmental Policy Act, ${ }^{63}$ requiring, among other things, that the Army Corps of Engmeers prepare assessments of the environmental effects of all autlorized projects. ${ }^{64}$ Congress lias pressured the Corps to follow these statutory dictates strictly. In 1970 the House Committee on Government Operations exhorted the Corps to intensify the environmental review im its permit process. ${ }^{65}$ The Committee repeated its demand in 1972, statimg that the Corps should "exercise its jurisdiction over navigable waters of the United States to the fullest extent available . . . ."66 Moreover, according to the Committee, the Corps sliould require that applicants for section 10 permits "affirmatively show that the proposed work is in the public interest."67

Even before this combimation of statutory demands and congressional prodding, the Corps had instituted its own "public imterest review."68 This review imcludes consideration of ecology, pollution, effects on fisl and wildlife, aesthetics, and conservation. ${ }^{69}$ A public interest review is not pro forma: the Corps has noted that "[t]he decision as to whetlier a permit will be issued must rest on an evaluation of all relevant factors . . . ."70 In addition, the Corps has begun to prosecute

62. 16 U.S.C. $\S 662$ (a), (f) (1976). This Act apphies to animals such as the wild burro.

63. Pub. L. No. 91-190, 83 Stat. 852 (1970) (codified at 42 U.S.C. $\$ \$ 4321-4347$ (1976)).

64. 42 U.S.C. $§ 4332$ (1976). In addition, the Federal Water Pollution Control Act Amendments of 1972, Pub. L. No. 92-500, 86 Stat. 816 (codified at 33 U.S.C. $\$ \S 1251-1376$ (1976)), created a comprehensive pollution-control program. The Corps of Engineers was authorized to issue permits for discharges of dredged material, 33 U.S.C. $§ 1344$ (1976), also covered under section 10 of the 1899 Rivers and Harbors Act, id. $\S 403$. The Federal Water Pollution Control Act Amendments are concerned only with pollutant discharges. Id. $\$ \S 1251,1342$ (1976). The environmental review under sections 9 and 10 , on the other hand, looks at the environmental impact of the entire waterway-related project. Projects may have significant onshore effects (e.g., the destruction of a valuable forest) or may affect fish and wildlife. Neither of these factors is considercd in the environmental review conducted by the Corps, the Environmental Protection Agency, or state agencies under the procedures established by the 1972 Federal Water Pollution Control Act Amendments. Therefore, the environmental review of the Corps-concerning structures in navigable waters-is stronger and inore far reaching under the Rivers and Harbors Act than under the Federal Water Pollution Control Act Amendments.

65. H.R. REP. No. 917, supra note 2.

66. H.R. REP. No. 1323, supra note 2, at 6.

67. H.R. REP. No. 917 , supra note 2, at 8.

68. 33 C.F.R. $\S \S 209.110-.120$ (1969).

69. Id. $\$ 209.120$.

70. Id. Not surprisingly, several environmental commentators have welcomed the use of sections 9 and 10 as environmental tools. See Barker, Sections 9 \& 10 of the Rivers and Harbors Act of 1899: Potent Tools for Environmental Protection, 6 EcoLoGY L.Q. 109 (1976); Castro, The Use of Corps of Engineers Permit Authority as a Tool for Defending the Environment, 11 NAT. Resources J. 1 (1971); Kramon, Section 10 of the Rivers and Harbors Act: The Emergence of a New Protection for Tidal Marshes, 33 MD. L. REv. 229 (1973). Some have recognized the benefits of exploiting the weaknesses of sections 9 and 10: "[I]t is possible to creatively use the permit 
violators of section 9 and 10 permit requirements. These prosecutions, based on environmental concerns, have been most numerous in Florida, where a popular means of land development has been to fill in marshes and dredge canals in order to develop waterfront housing. ${ }^{71}$ Recent court rulings extending the jurisdiction of the Corps to include onshore projects that affect navigation and the environment ${ }^{72}$ have rendered the approval power under sections 9 and 10 an even more potent environmental tool in these situations.

The decision in Zabel v. Tabb ${ }^{73}$ confirmed the Corps' broad power to conduct a review of environmental impact. The Zabel court affirmed the Corps' denial of a permit to fill eleven acres of navigable waters near Tampa, Florida for the construction of a trailer park. In its public interest review, the Corps had found that the filling imposed no obstruction to navigation, but it denied the permit on the grounds that the Fish and Wildlife Service was adaniantly opposed to the project in any form. The question before the court was whether the Corps could deny a section 10 permit for reasons unrelated to navigation. ${ }^{74}$ The court's unequivocally affirmative response drew support from the $\mathrm{Na}$ tional Environmental Policy Act, ${ }^{75}$ the Fish and Wildlife Coordination Act, ${ }^{76}$ and the voluminous legislative histories accompanying both bills. ${ }^{77}$ Significantly, the court rehed on these acts and reports, rather than delving imto the 1899 Act and its history. ${ }^{78}$ In short, the Zabel court read sections 9 and 10 as sanctioning environmental, as well as navigational, regulation by the Corps.

authority to collaterally attack an environmentally unsound project which for various reasons may not be susceptible to attack on other grounds." Castro, supra at 30.

71. See, e.g., United States v. Joseph G. Moretti, Inc., 526 F.2d 1306 (5th Cir. 1976) (Moretti II); Weiszmann v. District Eng'r, United States Army Corps of Eng'rs, 526 F.2d 1302 (5th Cir. 1976); United States v. Sexton Cove Estates, Inc., 526 F.2d 1293 (5th Cir. 1976); United States v. Underwood, 344 F. Supp. 486 (M.D. Fla. 1972).

72. See note 35 supra.

73. 430 F.2d 199 (5th Cir. 1970), cert. denied, 401 U.S. 910 (1971).

74. $430 \mathrm{~F} .2 \mathrm{~d}$ at 203 .

75. 42 U.S.C. $\$ \S 4321-4347$ (1976).

76. 16 U.S.C. $\$ \$ 661-666(1976)$.

77. The legislative history for the National Environmental Policy Act is found at S. REP. No. 296, 91 st Cong., lst Sess. (1969); H.R. ReP. No. 378, 91st Cong., 1st Sess. (1969), reprinted in [1969] U.S. Code Cong. \& AD. News 2751; Conf. Rep. No. 765, 91 st Cong., lst Sess. (1969), reprinted in [1969] U.S. CODE CONG. \& AD. NEws 2767. There is no legislative history for the Fish and Wildlife Coordination Act of 1934. The legislative histories for the 1958 and 1965 amendments to that Act are found at S. REP. No. 1981, 85th Cong., 2d Sess., reprinted in [1958] U.S. CODE CoNG. \& AD. News 3446; and H.R. REP. No. 254, 89th Cong., 1st Sess., reprinted in [1965] U.S. CODE CONG. \& AD. NEws 1864.

78. $430 \mathrm{~F} .2 \mathrm{~d}$ at $209-14$. 


\section{B. Third-Party Environmental Suits.}

While the Corps has used sections 9 and 10 to obtain environmental goals, conservationist groups have used these sections in a different inanner. After projects have obtained Corps and Environmental Protection Agency approval, citizen groups have filed suit to block development of the projects by alleging faulty permit procedures. ${ }^{79}$ They have alleged either that the project lacks the requisite approval or that it was authorized under the wrong section. The discussion that follows analyzes the ambiguities in section 9 and section 10 that have been used to support these allegations.

\section{The Ambiguities of Section 9}

Section 9 of the Rivers and Harbors Act concerns four types of structures: dikes, dains, causeways, and bridges. If one of these structures is located "over or in" a waterway that is navigable in more than one state, the structure unust have both congressional and Corps authorization. ${ }^{80}$ Alternatively, if the structure is located in a waterway that is navigable in only one state, it needs only Corps and state legislative approval. ${ }^{81}$ The final clause of section 9 prohibits alterations of the plans of these structures after approval has been received, unless the alterations have been approved by the Corps. ${ }^{82}$

\section{A. The Meaning of "Over or In."}

The meaning of "over or $\mathrm{m}$ " in section 9 is a major interpretive problen. This phrase essentially defines the types of structures for which legislative approval is necessary.

1. The Corps Interpretation. The Corps has consistently construed the words "over or im" to mean "across," so that a bridge, dain, dike, or causeway nust "completely span" a waterway before legislative approval is required. By limiting legislative approval to the few projects that do totally span a navigable waterway, the Corps automatically enlarges its own area of exclusive control by placing under section 10 those dikes, dams, bridges, and causeways that do not totally span the waterway. The Corps adopted this definition of "over or in" long before it pronulgated the first regulations on the subject in $1946 .{ }^{83}$

\footnotetext{
79. See notes 89-117 infra and accompanying text.

80. 33 U.S.C. $\$ 401$ (1976).

81. Id.

82. Id.

83. Its [the Corps'] powers are of necessity vast. It may, for imstance, permit or refuse to permit a State to bridge or dam one of its own waters (sec. 9, act of Mar. 3, 1899); and it
} 
Since that time, these regulations have spoken of section 9 structures as being "across" navigable waterways. ${ }^{84}$ The most recent revision of these regulations is even more explicit: dikes and dams are categorized, by Corps definition, as a type of structure that "completely spans a navigable waterway and that may obstruct waterborne commerce." 85

There are several environmental advantages of tlie Corps' definition of "over or in." First, the Corps' interpretation draws a convenient line between section 9 structures and section 10 structures. Some section 10 structures, such as bulkheads, jetties, and breakwaters, are functionally indistinguishable from dikes. ${ }^{86}$ By defining a dike as necessarily spanning a waterway, the Corps has imposed a workable distmction between the structures. Next, the resultant widening of Corps control insures a consistent and nonpolitical environmental review of proposed projects. Congress, unlike the Corps, need not follow environmental regulations or standards. ${ }^{87}$ Congress may approve a project based on purely political considerations without considering the ecological inerits of the structure. Finally, an environmental group that disagrees with the Corps' approval of a project may seek to enjoin the construction of the project on the grounds that the Corps did not follow the dictates of various environmental statutes or that tlie environmental

\footnotetext{
has the authority to permit or refuse to permit any obstruction, except the class which extend clear across a stream, however large and important, if any navigable waters of the United States, whether interstate of [sic] intrastate waters (sec. 10, idem.).

Hearings on General Dam Legislation Before the House Comm. on Interstate and Foreign Commerce, 64th Cong., 1st Sess. 18 (1916) (statement of Limdley M. Garrison, Secretary of War) (emphasis added).

84. See, e.g., 33 C.F.R. § 209.120(a)(1), (a)(2), (d) (1967); 33 C.F.R. § 209.50(a) (1946).

85. 33 C.F.R. \& 321.2(b)-(c) (1978).

86. Webster's THIRD NEW INTERNATIONAL DictionaRY (3d ed. 1961) offers the following definitions of these terms:

bulkhead . . . : a stone, wood, or concrete structure or partition designed to resist pressure or to shut off water, fire, or gas; esp: the retaining wall along a waterfront . . . . Id. 293.

breakwater . . . an offshore structure for breaking the force of waves (as to protect a harbor or beach) ....

Id. 273.

jetty . . . : a structure (as a pier or mole of wood or stone) extended into a sea, lake, or

Id. 1215.

river to influence the current or tide or to protect a harbor ....

dike ... : a wall or fence of turf or stone; ... a bank usu. of earth constructed to control or confine water: LEVEE . . . : a raised causeway . . . . Id. 632 .

The second edition of this dictionary was used in Hart \& Miller Islands Area Environmental Group, Inc. v. Corps of Eng'rs, 459 F. Supp. 279 (D. Md. 1978). See text accompanying notes 11117 infra.

87. See, e.g., Environmental Defense Fund, Inc. v. Froehlke, 473 F.2d 346 (8th Cir. 1972). "We recognize that Congress has the right to authorize projects and to exempt them from the provisions of NEPA ...."Id. at 355 (emphasis in original).
} 
impact statement for the project is faulty. ${ }^{88}$ These are the normal means of obtaining judicial review of an administrative action. Congressional approval of a waterway project, on the other hand, is immune to these challenges. Congress may ignore prior environmental legislation, and its actions may be judicially overturned only if they are unconstitutional. It is much easier to prove that the Corps did not follow certaim environmental standards im its approval process than it is to prove that congressional approval of a waterway-related project is unconstitutional.

2. The Judicial Interpretation. The Corps' interpretation of "over or $\mathrm{m}$ " is desirable because it is simple to apply and it promotes wide and uniform environmental review. The judicial imterpretations of these words have largely ignored these considerations. As a result, the judicial constructions of "over or in" have produced random results, soune of which are marked by contradictory reasoning. Moreover, the courts have also disregarded the practical consequences of their holdings for both the Corps and the environment.

The leading case concerning the meaning of "over or in" is Citizens Committee for the Hudson Valley v. Volpe. ${ }^{89}$ A controversy arose over the construction of the proposed Hudson River Expressway between Tarrytown and Crotonville, New York. Approximately four miles of the highway were to rest on fill material that would have projected 1300 feet into the river. ${ }^{90}$ Because the filled area would not have spanned the river, the Corps issued a section 10 permit for the project without requiring legislative approval. ${ }^{91}$ Local citizens groups that opposed the highway filed suit to enjoin the project on the ground that it involved dikes and causeways, and therefore needed congressional approval under section 9.

The Hudson Valley court by implication ruled that dikes, dams, bridges, or causeways need not totally span a waterway to be subject to section 9 congressional approval. The opimion discussed the definition of a dike and concluded that any rock wall separating water from fill unaterial was a "dike" for the purposes of section 9, regardless of whether it spanned the waterway. ${ }^{92}$ The court rehed upon Webster's New International Dictionary and the fact that the structure had been

88. The substantive judicial review of Environmental Impact Statements is limited, however. See Vermont Yankee Nuclear Power v. Natural Res. Defense Counsel, 435 U.S. 519 (1978). (1970).

89. 302 F. Supp. 1083 (S.D.N.Y. 1969), affd, 425 F.2d 97 (2d Cir.), cert. denied, 400 U.S. 949

90. 302 F. Supp. at 1086.

91. Id. at $1086-87$.

92. Id. at $1088-89$. 
referred to as a dike in the state's engineering plans..$^{93}$ Nowhere did the opinion examine the administrative practice, the administrative interpretation, or even the meager legislative history of the 1899 Act for guidance. ${ }^{94}$

The decision in Petterson v. Resor ${ }^{95}$ threatened to undercut the environmentahists' use of sections 9 and 10. In Petterson the plaintiffs sought to enjoin the expansion of the Portland International Airport onto filled area projectimg into the Columbia River. The Corps approved the project under section 10 , but the environmentalists contended that the filled material would be retained by a dike, thus requiring congressional approval under section $9 .{ }^{96}$ In a relatively brief opinion, the court addressed the navigational issues, placing great weight upon the Corps' interpretation of the 1899 Act and the previous administrative application. ${ }^{97}$ The court concluded that under the Corps' view of the phrase "over or in," congressional approval was necessary only for those structures that totally spanned the waterway; therefore, no congressional approval was needed for this project.98

Unfortunately, Petterson lacks a firm basis for its holding. The opinion referred to the legislative history of the 1899 Act, but only in

93. Id. The Corps normally interprets "dike" for purposes of section 9 congressional approval to mean a structure spanning a navigable waterway. See text accompanying notes 80-86 supra. In Hudson Valley the Corps offered another definition of dike, which the court rejected. 302 F. Supp. at 1088-89. The court did not consider the standard administrative interpretation:

The defendants urge that Congress, in using the term "dike" in I899, meant a structure that would be within the definition set forth in Chambers Technical Dictionary, $p$. 273 (3d Rev. ed. with Supp. 1958), which was originally published in 1940, i.e., "a wall or einbankment of timber, stone, concrete, fascines, or other inaterial, built as a training works for a river so as rigidly to confine flow within definite limits over the length treated." From this defimition they conclude that a real dike must substantially affect navigation since it confines river flow, and since the dikes in their plans do not substantially affect navigation they are not dikes as Congress used the term.

Id. at 1088. This deviation from the standard Corps definition of dikes as structures totally spanning a waterway may well have affected the court's reasoning. There is no indication why this different definition was offered to the court. Moreover, any attempts to inpute a specific congressional meaning to a term in the 1899 Act are disingenuous, given the deception involved in passing the Act. See notes 54-60 supra and accompanying text.

Other courts have accepted unquestioningly the proposition that dikes that do not totally span a waterway fall under the section 10 power of the Corps. See, e.g., United States v. Bailey, 467 F. Supp. 925, 926 (E.D. Ark. 1979) (a dike constructed in violation of the conditions set out in its section 10 permit); Umited States v. Cameron, 466 F. Supp. 1099, 1100-01 (M.D. Fla. 1978) (a dike on low-lying portion of lake-front property).

94. The bulk of the opinion discussed the plaintiffs' standing to sue, the primary issue upon which the case was.upheld on appeal. 425 F.2d 97 (2d Cir.), cert. denied, 400 U.S. 949 (1970).

95. 331 F. Supp. 1302 (D. Ore. 1971), remanded as moot, 494 F.2d 124 (9th Cir. 1974). See also Citizens Comm. for Environmental Protection v. Umited States Coast Guard, 456 F. Supp. 101 (D.N.J. 1978), which follows Petterson closely.

96. 331 F. Supp. at 1303 .

97. Id. at 1306 .

98. Id. 
vague terms. ${ }^{99}$ As a result of the deception involved in passing the Act, the legislative history offers no real clue about the appropriate ineaning of "over or in." In addition, the Petterson court gave great weight to the age and consistency of the Corps' interpretation but offered no rationale to support its rehance. ${ }^{100}$ The opinion did state that without the requirenent that the structure totally span the waterway, dikes would become indistinguishable from breakwaters, jetties, or bulkheads. ${ }^{101}$ The court was otherwise unpersuasive, however, in its effort to show the administrative and environmental advantages of the Corps' interpretation.

The Petterson opinion was rendered noot on appeal because the City of Portland cancelled the airport project. ${ }^{102} \mathrm{Had}$ the opinion been affirmed on appeal, the case might have substantially ended the environmentalists' use of sections 9 and 10. Stated simply, if the Corps' definitions are to control, the Corps will seldom be found to have followed the wrong procedure.

The court in Sierra Club v. Morton ${ }^{103}$ addrcssed the definition of "over or in" in a somewhat similar context. The Sierra Club and other environmental groups opposed the construction of a huge water-supply systein that would have transported water from the Sacramento River and its tributaries to water-starved Southern California. ${ }^{104}$ The project consisted of a series of canals, artificial lakes, dams, and pumping stations. ${ }^{105}$ One of the structures, the Peripheral Canal, would have spamied and obstructed the Middle River, a navigable waterway. The court found that Corps approval had not been obtained. ${ }^{106}$ In arriving at the conclusion that the canal would dam the Middle River-and fall

99. Id.

100. The issue underlying all of these cases concerns the amount of deference the courts should give the Corps' interpretation of "dike" and "over or in." An agency's imterpretation does carry great weight. See Quern v. Mandley, 436 U.S. 725, 738 (1978); Griggs v. Duke Power Co., 401 U.S. 424, 433-34 (1971); Udall v. Tallman, 380 U.S. 1, 16 (1965). An agency cannot, however, "bootstrap itself into an area in which it has no jurisdiction by repeatedly violating its statutory Inandate." Federal Maritine Comm'n v. Seatrain Line, 411 U.S. 726, 745 (1973). In looking at the uneaning of "over or in," the courts must do more than blindly follow the Corps interpretation, as the court did in Petterson.

101. 'To accept the plaintiffs' construction of Section 401 [section 9] would make Section 403 [section 10] ineaningless, because 'jetties,' 'breakwaters,' and 'fills,' mentioned in Section 403, all come within plaintiff's [sic] dictionary defintion of dikes." 331 F. Supp. at 1306.

102. 494 F.2d 124 (9th Cir. 1974).

103. 400 F. Supp. 610 (N.D. Cal. 1975).

104. Id. at $617-19$.

105. Id. at $620-21$.

106. Id. at 638. In Sierra Club the project was planned for an intrastate waterway. Under section 9 the project needed concurrent Corps and state legislative approval. In this case it was uncertain whether the California legislature had approved the project; the Corps definitely had not approved it. $I d$. at 627. 
under section 9 requirements-the court relied directly on Hudson $\mathrm{Val}$ ley. ${ }^{107}$ In Sierra Club, however, there was no factual question that the canal would totally span the river, effectively forming a dam. ${ }^{108}$

While this holding is not particularly remarkable, the court's reasoning is imtriguing. The opinion interpreted portions of section $9 \mathrm{~m}$ a manner that supported the Corps' definition of "over or in" instead of the Hudson Valley interpretation. Section 9 speaks of structures that would actually obstruct navigation. Section 10, on the other hand, refers to obstructions to navigable capacity, and the structures listed in that provision reflect this broader coverage. The Sierra Club court suggested that a proposed structure must have a section 9 permit only if it is proved that the structure will actually obstruct navigation. Under section 10 only proof of a potential obstruction is needed. ${ }^{109}$ According to this line of reasoning, Congress would only need to approve those dikes, dams, causeways, or bridges that actually obstruct navigation. Those that do not obstruct navigation, but merely affect navigable capacity, could be approved solely by the Corps under section 10. This view accords with the Corps' interpretation that "over or im" requires that the structure totally span the waterway. ${ }^{110}$ If the structure spans the waterway, it alınost certainly obstructs navigation. If the structure does not span the body of water, it may only affect navigable capacity. Sierra Club, therefore, actually interpreted section 9 to grant the Corps broader power than did Hudson Valley; it also recognized the limited need for congressional approval.

Hart \& Miller Islands Area Environmental Group, Inc. v. Corps of Engineers ${ }^{111}$ concerned the construction of a diked dredge disposal site in the northern Chesapeake Bay at Hart and Miller Islands. The principal issue was agam whether a dike that did not span the waterway required congressional approval. ${ }^{112}$ The court relied on Hudson Valley in two ways. First, it adopted the Hudson Valley dictionary definition of a dike and rejected the Corps' definition. ${ }^{113}$ Next, the court separately concluded that the words "over or in" do not demand that the structure span the body of water, since the project im Hudson Valley fell

107. Id. at 626 .

108. Id. The court ordered the procurement of a Corps permit. Id. at 627 .

109. Id . at 629-30. The court suggested that it was uncertain whether a seetion 10 permit was necessary for a dam, dike, bridge, or causeway if the obstruction did not actually affect navigation and thus needed no section 9 approval. Id. at 629 n.21.

110. See notes 83-85 supra and accompanying text.

111. 459 F. Supp. 279 (D. Md. 1978).

112. Id. at 283 .

113. Id. at $288-89$. 
under the provisions of section 9 and yet did not span the rivcr. ${ }^{114}$

In addition to its mistaken reliance on Hudson Valley, the Hart \& Miller court erred in several ways in interpreting "over or in" and "dike." First, the court intimated that the Corps had amended its published regulations in anticipation of that litigation in order to require that a section 9 obstruction completely span the waterway. ${ }^{115}$ In fact, the Corps had consistently followed this interpretation of "over or in" for more than sixty years. ${ }^{116}$ Second, the Hart \& Miller court declined to follow the Petterson approach, reasoning that "[a]1though the [Petterson] court apparently relied upon the legislative history of Sections 9 and 10, the court does not indicate exactly which portions of the history were relied upon and does not specifically refer to any particular docuinents, Congressional or otherwise."117 The Hart \& Miller court itself declined to seek any guidance from the history of either the 1890 Act or the 1899 Act. The decision not to rely on the direct legislative history was wise; the misrepresentations about the 1899 Act at the time of passage render the authority of an interpretation of congressional intent ratler dubious. The courts should be hesitant to read the 1899 Act narrowly and absolutely, as they would a statute that was carefully drafted by Congress. Rather, the courts should interpret sections 9 and 10 liberally by looking at their purpose, the administrative structure they create, and the most efficient method of admimistration. The Corps' definitions of "dike" and "over or in" incorporated these considerations, while those of Hart \& Miller did not. Finally, the Hart \& Miller opimion disregarded the practical difficulties created by its lolding. For the purposes of sections 9 and 10, it would be impossible to distinguish between a breakwater, bulkhead, jetty, or dike without concluding that "over or in" was imtended to mean "across." The Hart \& Miller court overlooked the administrative confusion it would cause by disturbing a convenient boundary between legislative and Corps power over obstructions to navigable waters.

\section{B. The Meaning of "Intrastate Waterway."}

Once a structure becomes subject to section 9 approval requirenuents, the second nuajor ambiguity in section 9 must be addressed. That anıbiguity concerns the definitions of "intrastate" and "interstate" waterways. For waterways that are navigable in more than one state, the command is clear: Congress and the Corps must approve any pro-

114. Id. at 290.

115. Id. at 289-90.

116. See notes 83-85 supra and accompanying text.

117. 459 F. Supp. at 285. 
posed bridge, dam, dike, or causeway. ${ }^{118}$ By contrast, for "rivers and other waterways, the navigable portions of which lie wholly within the limits of a smgle State,"l 19 concurrent approval of the Corps and the state legislature will suffice. The terms "intrastate" and "interstate" serve as abbreviations for these two types of waterways. No case has attempted to delineate the distinctive eleinents of an mterstate or an intrastate waterway. Environmental groups may use this imterpretive difficulty as a basis for challenging the authorization of projects.

The first aunbiguity in section 9, concerning the definition of "over or in," blurs the limits of the Corps' exclusive approval power. This second uncertainty, on the other hand, concerns the division of the legislative approval power contained within section 9. The concepts of "intrastate" and "interstate" waterways determine whether the state legislature or Congress must approve the proposed project.

The problem lies in determining which waterways are independent and navigable only in one state. Many busy waterways are navigable only in one state yet are tributaries of other, interstate waterways. ${ }^{120}$ Arguably, rivers that are navigable in only one state but join with larger, interstate bodies of water should be subject to the same approval requireinents as interstate waterways. Presently, no guidelines have been issued to distinguish intrastate and interstate bodies of water. Indeed, when called upon in 1892 to determine whether the East River in New York was interstate, the United States Attorney General consulted the Encyclopaedia Americana before ruling that the river was not an interstate waterway. ${ }^{121}$

The Supreme Court, in Economy Light \& Power Co. v. United States, ${ }^{122}$ avoided the issue when discussing a proposed dan1 across the Des Plaines River. In Economy Light the Court spoke of the river as a "natural interstate waterway," 123 although it hes wholly within the state of Illinois. Although the case concerned whether the Des Plaines is navigable and thus subject to federal control under section 9, the Court did not indicate the proper approval method-authorization by Con-

118. 33 U.S.C. $\S 401$ (1976).

119. $I d$.

120. A listing of these waterways would include the Des Plaines River (part of the connection between Lake Michigan and the Mississippi River), RaND MCNaLly \& Co., 1979 Commerclal Atlas and Marketing Guide 191 (110th ed. 1979); the Patapsco River (linking the port of Baltinore with the Chesapeake Bay), id. 262; the Raritan River (connecting the Delaware River to lower New York Bay), id. 356; and the Schuykill River (emptying into the Delaware River), id. 449.

121. 20 OP. ATT'Y GEN. 479, 481 (1892).

122. 256 U.S. 113 (1921).

123. Id. at 124 . 
gress or approval by the state-for the dam in this case.

The Patapsco River in Maryland presents a compendium of the potential problems under this provision of the Rivers and Harbors Act. Because the Patapsco is a tidewater river that widens almost imperceptibly to become part of the Chesapeake Bay, ${ }^{124}$ there is no abrupt transition from intrastate to interstate waterway. At present, most of the river's branches are navigable by oceangoing vessels, and much of the river constitutes the Port of Baltimore. ${ }^{125}$ Lacking any guidance as to whether congressional approval is necessary for a section 9 structure or whether state legislative approval will suffice, anyone wishing to build such a structure can only look to prior congressional action to determine the extent of federal control over Baltimore Harbor, the Patapsco River, and Chesapeake Bay.

Congress has passed inuch navigation-related legislation concerning Baltimore Harbor. In 1958 Congress passed a series of enactments that, among other things, prohibited the deposit of refuse in Baltimore Harbor, ${ }^{126}$ required Corps permits for both dumping in the harbor ${ }^{127}$ and transporting material dredged from the harbor, ${ }^{128}$ and required the Secretary of the Army to appoint a "supervisor" for Baltimore Harbor to enforce these provisions. ${ }^{129}$ Along with these regulations, Congress further extended its control over the Baltimore Harbor area by defining it as "the tidal waters of the harbor of Baltimore and its adjacent and tributary waters, and so much of the Chesapeake Bay and its tributaries as he within the State of Maryland . ..."130 The federal government clearly would have control over navigation in the Chesapeake Bay smce it is an interstate waterway; ${ }^{131}$ this broad definition enlarges that control to cover the coumecting tributaries as well. Congress had already exercised this control in 1930 by granting a blanket authorization for all private dredging meeting Corps approval that occurred "in the

124. National Oceanic \& Atmospheric administration, Map of Chesapeake Bay, NoRThern PART. No. 12260 (Apr. 3, 1976).

125. In 1978 the Port of Baltimore was the fifth largest port in the nation in terms of tonnage and the third largest in terms of the dollar value of cargo handled. MARYLAND PORT ADMINIStration, 1978 Foreign Statistical Commerce Report, Port of Baltimore 10 (1979). The port shipped over 33,000,000 tons of cargo in 1978, 92\% of which was for import or export. Id. 1 . This is precisely the type of waterborne commerce meant to be protected by the Rivers and Harbors Act of 1899.

126. Rivers and Harbors Act of 1958, Pub. L. No. 85-802, $§ 1(7), 72$ Stat. 970 (codified at 33 U.S.C. \& 451(a) (1976)). The enactment of this section brought the Harbor of Baltinore within the provisions of 33 U.S.C. $\$ \$ 441,444,449$ (1976).

127. 33 U.S.C. \& 444 (1976).

128. Id. $\$ 449$.

129. Id. § 451 .

130. Id. § 451(b).

131. See id. $\S 401$. 
navigable waters of the United States included within the state of Maryland."132 Subsequently, Congress declared a portion of the Patapsco River "nonnavigable" in 1 order to waive the Corps' approval requirements for filling operations related to Baltimore's extensive urban renewal. 133

The scope of these regulations and the broad definition given to Baltimore Harbor suggest two conclusions. First, Congress intended strict control over all navigational aspects of the Port of Baltimore. Second, Congress viewed the Chesapeake Bay and Patapsco River as one body of water for the purposes of section 9 . The implication is that all intrastate waterways connecting with interstate waterways should be treated as interstate waterways for the purposes of section 9 when both bodies of water accommodate waterborne commerce. This conclusion, however, has never been confirmed judicially.

The resulting uncertainty creates difficulties for developers, industries, state agencies, and urban planners in determining the proper route for legislative and administrative approval of their projects. If the interested party obtains a Corps permit and state legislative approval, the project inay nevertheless be blocked by a judicial finding that the waterway is really interstate and that congressional authorization for the project is required. Conversely, in order to avoid this vulnerability, the party must obtain congressional approval-a inost difficult undertaking. ${ }^{134}$ Moreover, seeking congressional approval may be unduly rigorous for a small diking and filling operation or a short causeway. In these instances congressional approval offers no greater protection to navigation than would Corps approval alone, since the Corps possesses the greater scientific and technical expertise in dealing with navigation. Furthermore, requiring congressional approval can have adverse environmental effects because small developers may ignore all administrative approval requirements if congressional approval is required but is difficult and costly to obtam. ${ }^{135}$ As a result, no governing body will conduct an environmental review of the project, and the developers will have risked only a shight

132. Act of July 3, 1930, ch. $847, \S 12,46$ Stat. 949 (codified at 33 U.S.C. $\S 465$ (1976)).

133. 33 U.S.C. \& 59(i) (1976).

134. Congressional approval is not easy to obtain. First, the proponents of the waterwayrelated project unust find a inember of Congress willing to sponsor the needed legislation. The heavy deinands upon congressmen inay make them unwilling to assume an additional burden, particularly if the project is small or controversial. Proponents of the project must shepherd the proposed authorization through the appropriate committees and obtain full House and Senate approval. This process may take well over a year and may entail great lobbying costs. Moreover, there is no guarantee that at some point in the process the bill will not become a victim of unrelated pohitical coinpromises, agreements, or battles. See 34 Cong. Q., ALMANAC xxi-xxv (1978).

135. See note 148 infra and accompanying text. 
chance of prosecution.

\section{The Contradictions in Section 10}

Section 10 addresses the extent to which the Corps' administrative approval power over obstructions to navigation is exclusive. The first clause of the section is a broad ban on "any obstruction not affirmatively authorized by Congress, to the navigable capacity of any of the waters of the United States . . . ."136 The second clause lists various types of structures for which Corps approval alone is sufficient. ${ }^{137}$ The final clause grants the Corps power to approve dredging and filling operations in channels, as well as control over other activities that affect the navigable capacity of waterways. ${ }^{138}$

\section{A. The Narrow View of the Corps' Power.}

The interpretive problem of section 10 lies in reconciling the first clause with the last two clauses. One possibility is to read the first clause as a flat ban and the second and third clauses as narrowly drawn exceptions to that ban. All structures not specifically enumerated in the last clauses would then need congressional approval. The Supreme Court suggested this view in United States v. Republic Steel Corp. ${ }^{139}$ The case concerned the discharge of industrial wastes into the Calumet River, a navigable waterway. These wastes contained deposits that silted the Calumet, rendering it useless for navigation by large vessels. This discharge was made without a section 10 permit. ${ }^{140}$

The Republic Steel opinion focused mainly on section 13 (the Refuse Act), ${ }^{141}$ but it also addressed the breadth of the first clause of section 10. Justice Douglas, speaking for the Court, found that the first clause forbade any obstruction to navigable capacity:

We can only conclude that Congress planned to ban any type of "obstruction," not merely those specifically made subject to approval by the Secretary of the Army [the Corps]. It seems, moreover, that the first clause bemg specifically aimed at "navigable capacity" serves an end that may at times be broader than those served by the other clauses. Some structures mentioned in the second clause may only deter movements in commerce, falling short of adversely affecting navigable capacity. And navigable capacity of a waterway may conceivably be affected by means other than the excavations and fills

136. 33 U.S.C. $§ 403$ (1976).

137. $I d$.

138. $I d$.

139. 362 U.S. 482 (1960).

140. $I d$. at $483-84$.

141. 33 U.S.C. $§ 407$ (1976). 
mentioned in the third clause. We would need to strain hard to conclude that the only obstructions banned by $\S 10$ are those enumerated in the second and third clauses. ${ }^{142}$

The Court concluded that the waste deposits were obstructions to navigable capacity and were forbidden. The deposits, however, fell under the third clause of section 10 , which made Corps approval sufficient. Because the defendants lacked a section 10 permit, the Court remanded the case for further factfinding prior to a determination of the appropriate remedy. 143

This literal reading of section 10 suggests that the Corps' approval power over obstructions is very narrow-that is, it is limited strictly to the structures and activities histed in the last two clauses of section 10 . Structures not in that list or not known to Congress in 1899 therefore need congressional approval in order to avoid the ban of the first clause. Not only does this approach narrow the power of the Corps, but it also creates a potential source of higation by environmentalist groups. By arguing that a Corps-approved structure does not fall within the definition of any of the structures listed in the last two clauses, conservationists may be able to require congressional approval for the disputed project (because of the broad ban in the first clause), and thereby effectively kill the project. This tactic was used in both Hudson Valley ${ }^{144}$ and Hart \& Miller. ${ }^{145}$

The interpretation in Republic Steel also lessens the likelihood that a project will be subjected to environmental review. As discussed earher, ${ }^{146}$ when Congress approves a project, it nuay be influenced by political considerations. The Corps, on the other hand, is required to conduct an environmental review each time it considers an application. ${ }^{147}$ If projects not histed in the second and third clauses of section

142. 362 U.S. at 487.

143. Id. at 493.

The more compelling analysis of the Act came from Justice Harlan, who dissented in Republic Steel. He reviewed the scanty legislative history of both the 1899 Act and the 1890 Act that preceded it. He subscribed to the reasoning of Wisconsin v. Illinois, 278 U.S. 367 (1929), and viewed the word "obstruction" in section 10 as referring only to those structures enumerated in the last two clauses of the section. 362 U.S. at $504 \mathrm{n} .25$ (Harlan, J., dissenting). This was a strict view of the Act in keeping with Justice Harlan's philosophy of judicial restraint. Id. at 503. Justice Harlan prefaced his analysis with the warning that "the provisions of the governing statute are complex and their legislative history tortuons." Id. at 493. The reasoning that followed that statement reflects this caveat, although it ignores Congress' reason for including a broad prohibition clause in the 1890 Act. Justice Harlan made no mention of Willamette Iron Bridge Co. v. Hatch, 125 U.S. 1 (1888), or of any of the cases leading up to the 1890 Act in this context. See notes $31-34$ supra and accompanying text.

144. See notes 89-94 supra and accompanying text.

145. See text accompanying notes 111-17 supra.

146. See note 134 supra.

147. If the project is controversial enough to spawn environmental higation, it will probably 
10 required congressional approval, they would not receive a binding environmental review. ${ }^{148}$ If, on the other hand, they were subject to Corps control, the Corps either could deny the permit if the project was environmentally unacceptable or could condition the issuance of the permit on the addition of ecological safeguards to the project. By indicating that projects not specifically listed under the second and third clauses of section 10 must have congressional approval, the Republic Steel opinion runs counter to the current trend, which favors increased Corps jurisdiction and hence increased environmental review. ${ }^{149}$

\section{B. The Broad View of the Corps' Power.}

From a conservationist's standpoint, the preferred Supreme Court interpretation of section 10 cane in the 1929 case of Wisconsin v. Illinois. ${ }^{150}$ This dispute concerned the diversion of large amounts of water into the Chicago River and the Chicago Samtary District Canal. The diversion reversed the flow of the river and carried Chicago's sewage soutlrward to the Mississippi River, via other rivers. This massive project also lowered the level of Lake Michigan six inches, inipeding navigation. ${ }^{151}$ Although the diversion of water is not expressly inentioned in section 10 as an activity over whicls the Corps holds approval power, the Supreme Court found that the Corps was entitled to issue a section 10 permit and that Illinois had violated the terms of that permit. ${ }^{152}$

The Court, in oft-quoted language, set out its view of the administrative power of the Corps:

The true intent of the Act of Congress was that unreasonable obstructions to navigation and navigable capacity were to be prohibited, and in the cases described in the second and third clauses of Section 10, the Secretary of War, acting on the recommendation of the Chief of Engineers, was authorized to determine what in the particular cases constituted an unreasonable obstruction.

This construction of Section 10 is sustained by the uniform practice of the War Department for nearly thirty years. Nothing is more convincing in interpretation of a doubtful or ambiguous statute. ${ }^{153}$

This reading of the Act and the lolding in the case suggest that the

be difficult to obtain the initial support uecessary from key congressmen to present the issue to the House or Senate. See note 134 supra.

148. Indeed, if congressional approval were required, many small developers would simply seek to evade the law, which, of course, would lead to even less environmental review. See Johnson, supra note 35 , at 364-72.

149. See note 35 supra.

150. 278 U.S. 367 (1929).

151. Id. at 400 .

152. Id. at 417-18, 420-21.

153. Id. at 413 (emphasis added). 
Corps has very broad power to approve obstructions to navigable waters, a power that extends beyond the structures and activities specifcally listed in the second and third clauses of section 10 . This view is consistent with the purpose of the first clause of section 10 as it was originally enacted in 1890 . The broad ban in that clause was meant to assert exclusive federal control over obstructions to navigable waters. Given the unclear legislative history of the 1899 Act, the ban may have been carried over from the 1890 Act into the 1899 Act merely to prevent a renewed assertion of state control. Therefore, the clause may not have been intended as a limitation on Corps power under section 10. ${ }^{154}$ Moreover, under the 1890 Act the Corps' exclusive approval powers were quite broad. ${ }^{155}$ These powers were narrowed somewhat in 1899 by the section 9 provision for legislative approval of certain structures. Congress may, however, have intended to continue the broad exclusive powers of the Corps under the 1899 Act, with section 9 covering only four particular types of structures, and with the first clause of section 10 simply reaffirming the federal primacy over all navigable waters of the United States.

According to this view, the structures listed in the last two clauses of section 10 are merely examples of Corps power, not actual limits on that power. The essentially vague nature of the terms used to describe these structures indicates that they were meant to be merely exemplary. Therefore, Corps jurisdiction, and hence, environmental review, should extend to all types of obstructions in navigable waters, unless they are of the types subject to congressional approval under section 9 .

\section{The Inconsistencies of the Third Clause.}

The third clause of Section 10 prohibits actions to "excavate or fill, or in any manner to alter or modify the course, location, condition, or capacity of, any port, roadstead, haven, harbor, canal, lake, harbor of refuge, or inclosure within the limits of any breakwater, or of the chan-

154. An Attorney General's Advisory Opinion on the same water diversion, roughly contemporaneous with the decision im Wisconsm v. Illinois, 278 U.S. 367 (1929), supports this conclusion. The opinion recognized the choice between the interpretation of section 10 used in the Republic Steel case and that used im the Wisconsin case. 34 OP. ATT'Y GEN. 410, 411 (1925). The opinion concluded that section 10 placed exclusive approval power with the Corps, with certain exceptions set out in section 9. Id. 411-12. Furthermore, the Attorney General found that

Congress evidently intended, by the Act of 1899 , to remove [the idea of plenary state control over obstrnctions to navigable waters] by asserting that, with respect to the navigable capacity of the waters of the United States, its failure to legislate should not be regarded as an implied authority to the States or to the citizens thereof to proceed to use the waters; but that the Federal Government should determine to what extent, if any, the navigable capacity of the water highways of the country might be affected. Id. 413.

155. See notes $40-46$ supra and accoinpanying text. 
nel of any navigable water of, the United States"156 without Corps approval. The bodies of water enumerated in this clause are primarily subparts of larger waterways. For example, a roadstead is merely the area of a river or harbor where ships may anchor. ${ }^{157}$ Most of these subparts of the waterway are related to daily commercial activity, yet in many cases the channels, harbors, or roadsteads may be a very small part of the entire waterway. Under the third clause of section 10, the Corps inay approve dredging or filling occurring only in these described portions of a waterway. Dredging or filling outside of these subparts, although in the same waterway, must, under the first clause of section 10, have congressional approval. ${ }^{158}$

This arrangement is a strange inversion of federal priorities. Congress' foremost interest in navigable waters is in fostering interstate commerce. ${ }^{159}$ Congress, however, delegated to the Corps authority over those subparts of waterways that actually do support waterborne commerce, while it retained control over alterations in the noncominerce bearing portion of the waterway. For example, the Corps can approve the filling of all major channels in the Hudson River, even though they are the very parts of the river that accommodate commercial activity. Congressional approval - in theory a higher level of federal protection for commerce-is necessary for dredging or filling in the rest of the Hudson River, where the impact on commercial activity may be nonexistent. The result of this inversion of interests is that the greatest level of protection is afforded to the parts of the waterways that affect daily commerce the least.

Congress has reacted in several ways to requests for approval of dredging and filling in parts of waterways that are not histed in the third clause of section 10. First, as in the case of the Chesapeake Bay, it has granted a blanket authorization for dredging and filling in any part of the Bay, subject to norinal Corps approval. ${ }^{160}$ Alternatively, Congress has declared several bodies of water to be "nonnavigable," thus remov-

156. 33 U.S.C. $\S 403$ (1976).

157. "Roadstead" is a synonym for one definition of "road":

In maritime law, an open passage of the sea that receives its denomination commonly from some port adjacent, which, though it lie out at sea, yet, $m$ respect of the situation of the land adjacent, and the depth and wideness of the place, is a safe place for the common riding or anchoring of ships.

BLACK'S LAW Dictionary 1193 (5th ed. 1979).

158. According to the Republic Steel reading of section 10, dredging and filling operations outside of channels are beyond the Corps' specified approval power and thus are obstructions within the prohibition of the first clause of section 10. See 362 U.S. at 487. See notes 139-45 supra and accompanying text.

159. See Gibbons v. Ogden, 22 U.S. (9 Wheat.) 1 (1824).

160. 33 U.S.C. $\S 465$ (1976). 
ing them from the requirement of federal authorization altogether. ${ }^{161}$ Finally, in some instances Congress has joined a declaration of nonnavigability with an authorization for dredging and filling, and has occasionally made the project subject to normal Corps approval as well. ${ }^{162}$ This action is rather anomalous, smce a declaration of nonnavigability by definition removes the waterway from any federal control, ${ }^{163}$ but an authorization for dredging subject to Corps approval is effectively a reaffirmation of that federal control.

\section{A Model Redraft of Sections 9 and 10}

\section{A. The Need for a Redraft.}

Public interest groups will probably continue to exploit the weaknesses of sections 9 and 10 of the Rivers and Harbors Act of 1899 to achieve their own goals concerning particular waterway-related projects. These suits, when successful, limit the scope of the Corps' environmental review over smaller, more mundane projects and subject these projects instead to the hazards of congressional approval. If these suits continue, the courts may eventually be moved to settle the problem of the proper division of approval power. The prior judicial apphcation of this Act suggests that this process will be very slow and uncertain at best. Eighty years after the passage of the Act, the question of its applicability to certam structures is still being litigated, as, for example, in Sierra Club v. Morton. ${ }^{164}$ Should this saine tortuous process apply to the question of the apportionment of approval power, it nay be many years before a workable judicial pronouncement emerges. If Hudson Valley and Hart \& Miller are any indication of the quality of these rulings, the judicial consideration of this question is off to a most inauspicious start.

A congressional revision of sections 9 and 10 would resolve many of the problems of their application and interpretation. The sections were inartfully drafted. A careful revision, benefiting froin eighty years of experience in applying the 1899 Act, could eliminate these ambiguities. Terminology, inore precise and modern than that currently used

161. These waters include portions of the Calumet, id. $\$ \S 26,26 \mathrm{a}, 26 \mathrm{~b}$; the Mississippi, id. $\S 35$; Boston Harbor, id. $\S \S 56,59 \mathrm{f}$, San Francisco Bay, id. $\S 59 \mathrm{~h}$; and entire rivers, such as the Saint Mary's River in Ohio and Indiana, id. $\$ 43$.

162. Id. $\$ \$ 59 \mathrm{c}-1,-2,59 \mathrm{~h}, 59 \mathrm{k}, 59 \mathrm{n}, 590$.

163. Navigability defines the limits of federal control; those waters that are not navigable are by definition outside of federal control. Accordingly, no congressional or Corps approval is needed for any structure in nonnavigable waters. A granting of congressional consent or a requirement of Corps approval is therefore inconsistent with a declaration of nonnavigability. See note 35 supra.

164. 400 F. Supp. 610 (N.D. Cal. 1975). See text accompanying notes 103-08 supra. 
in sections 9 and 10, could be employed.165

In addition, the present delegation of approval power could be updated. It is no longer realistic to require an act of Congress to approve all dikes, dams, or causeways. Given the difficulty of obtaining congressional action, the requirement of full congressional approval for a small project involving dikes or causeways is disproportionate to the federal imterests involved; the Corps alone should be able to provide adequate assessment of the effects of such projects on navigation and the environment. Similarly, it is illogical to require state legislative approval for the construction of a dike, when the local environmental effects may be very small, but not to require state approval for a large dredging and filling project, when the local environmental effects may be significant. ${ }^{166}$

The requirement of state legislative approval for section 9 projects is particularly anachronistic. The cases preceding the passage of the 1899 Act indicate that the state interests' acknowledged in section 9 by the state legislative approval power were principally health and safety concerns. ${ }^{167}$ These concerns today are addressed in the environmental impact statements assembled by the Corps. Froin an environmental standpoimt, the Corps may be the more suitable governmental body to conduct the environmental review and approval: the Corps is more insulated from local political pressures than is a state legislature and is more open to suit if it disregards certam environmental criteria and procedures. 168

In short, if the Corps held most of the approval power over obstructions to navigable waters, all obstructions would be subject to a nore uniform environmental review. Also, the decisions of the Corps

165. The difficulties in defining dikes, jetties, bulkheads, and breakwaters have already been addressed. See note 86 supra.

166. See 33 U.S.C. $\$ 403$ (1976). This inconsistency arises from the requirement of section 9 that state legislatures approve dikes, dams, or causeways in-or across, according to the Corps' interpretation--intrastate waterways. These structures may have no real impact on either navigation or the adjacent communities. The dredging or filling of a harbor, canal, or lake, although exclusively under section 10 Corps control, may have a substantial effect on navigation and the surrounding region. Thus, even though the overall effects of all of those projects may be the same, the method for approving them is not the same and does not uniformly acknowledge the legitimate state and federal interests at stake.

167. See cases cited in note 33 supra.

168. See notes $84-88$ supra and accompanying text for a discussion of the superiority of the Corps in conducting environmental review.

Of course, any action by the Corps can be challenged under the Administrative Procedure Act, 5 U.S.C. $\$ \S 701-706$ (1976). That Act creates a cause of action for persons injured by agency actions if those actions are arbitrary, capricious, an abuse of discretion, a violation of a constitutional right, or beyond statutory authority. 
are more open to legal challenge than are the actions of state legislatures or Congress. Finally, the Corps approval mechanism is not as subject-as the legislative process - to caprice that could result im ignoring sound environmental objections to a project.

\section{B. The Model Redraft.}

The model revised section 9 could take the following form:

Section 9. It shall not be lawful to construct or commence construction of any dike, boom, weir, pier, wharf, bulkhead, breakwater, jetty, or any other structure in navigable waters, or to modify or alter the course, location, condition, or capacity of such waters, without the written approval of the Secretary of the Army, acting on the recommendation of the Chief of Engineers.

This new section 9 essentially incorporates most of the present section 10. It avoids the broad opening clause of the current section 10, which led to the implication in Republic Steel that Congress reserved to itself the approval right for all structures not enumerated in the two clauses that follow. 169 Instead of a broad reservation of congressional power and a subsequent list of enumerated Corps powers, all power is delegated to the Corps, subject to one congressional reservation in the new section 10. Moreover, the new section 9 speaks of "structures" in navigable waters, not "obstructions." "Structures" is a more precise term, since, with few exceptions, those things sought to be prohibited are structures of some sort. The filling of channels and the diversion of water, which affect navigable capacity, are covered by the second clause of the new section. This change avoids the question of what is an "obstruction" yet leaves a sufficiently broad grant of power to the Corps in the second clause to cover unforeseen hindrances to navigational capacity. The most common types of structures approved by the Corps are enumerated in the new section 9, for illustrative purposes only. Finally, dikes have been expressly removed from the provisions of the current section 9 and placed under exclusive Corps control in the new section 9. As discussed earlier, dikes are more akin to jetties, breakwaters, and bulkheads than they are to bridges or dams. ${ }^{170}$ In addition, dikes are more likely to hinder navigational capacity than to block navigation.

With an expanded and more precise delegation of power to the Corps under the new section 9 , the revised section 10 would read as follows:

Section 10. It shall not be lawful to construct or commence construction of any type of structure in navigable waters that totally

169. 362 U.S. at 487.

170. See the definitions in note 86 supra. 
spans the body of water, and that hinders present or potential interstate or foreign commerce, without the approval of Congress, acting on the recommendation of the Chief of Engineers.

This new section assumes the role of the current section 9 , but it narrowly reserves congressional approval for extraordinary structures only. By decreasing the necessity of such approval, this section facilitates the construction of many projects presently hindered by the current section 9 requirements.

The new section 10 substantially alters the provisions of the cur.rent section 9. The revised section 10 does not enumerate the structures over which Congress retains approval power; rather, it conditions that power on the characteristics of the structure. First, the structure inust span the waterway. If this requirement is met, it is likely that navigation is truly obstructed. Second, the structure must actually himder "present or potential interstate or foreign commerce." Not all structures that span a waterway necessarily hinder commerce. Bridges are one exanple, since the height and size of many bridges permit ships to pass beneath them unimpeded. ${ }^{171}$ The Corps would be authorized to make this threshold determination of hindrance. ${ }^{172}$ If the Corps finds that the structure would hinder present or future commerce, it must report the findings to Congress and inake a recommendation for or against congressional approval. An environmental impact statement would accompany this report.

This new wording better reflects the purpose of congressional interest in navigable waters: fostering commerce. If commerce is not significantly affected by a structure, Corps approval should suffice. In light of this purpose of fostering commerce, the new section 10 excludes from congressional approval all projects situated in waterways that supported commerce only in the past. Therefore, many of the smaller creeks and rivers, whicl may have accommodated commerce only in colonial times, are excluded from section 10 , and any structures in those waters need only be approved by the Corps under the new section 9.173

The inost significant change in the new section 10 is the elimma-

171. The General Bridge Act of 1946, 33 U.S.C. $\$ \S 525-533$ (1976), delegated congressional approval authority for bridges to the Corps. This function was transferred to the newly created Department of Transportation in 1966. 49 U.S.C. $\$ 1655(\mathrm{~g})(4)(1976)$. The model redraft accords with the General Bridge Act by effectively excluding bridges from congressional control. The independent delegation of power to the Secretary of Transportation remaims unaffected.

172. The word "hinders" is ambiguous at best, but short of histing what a hindrance to commerce is in terms of quantifiable ship delays, ship-size-capacity problems, and trade diversions, the term must suffice. It is also important to note that "hinders" is a milder word than "obstructs" or "blocks," so that an effect on commerce such as one of those listed above could constitute a hindrance.

173. See note 35 supra. 
tion of the state legislatures' approval power. This approval power was originally delegated to the states to allow for some expression of local interests and concerns. ${ }^{174}$ These local interests today are principally environmental imterests that can be examined adequately in the Corps' environmental impact statement. ${ }^{175}$ Moreover, the delegation of certam powers to the states-as well as to Congress-in 1899 was an attempt to save Corps control over navigable waters from complete unconstitutionality. ${ }^{176}$ Prior to the 1899 Act, this control was new and was timidly used. Since the passage of that Act, however, federal interests in navigable waters have become much stronger, and today federal control over navigable waterways is virtually exclusive. ${ }^{177}$

\section{CONCLUSION}

In their present form, sections 9 and 10 of the Rivers and Harbors Act of 1899 have governed the nation's navigable waterways for eighty years. From the outset these sections have been plagued by ambiguity, resultimg in frequent litigation.

The difficulties with sections 9 and 10 stem from several causes. First, the 1899 Act is poorly drafted. It also contams odd-and sometimes outdated-divisions of approval power. In addition, the Act's legislative history is confusing and difficult to evaluate, since Congress passed the 1899 Act with the intent of merely codifying existing law but in fact enacted a statute that greatly reformed that law.

Recently, environmental groups have exploited the ambiguities and varying interpretations of sections 9 and 10. Conservationists have alleged improper administrative approval in order to enjom various

174. See text accompanying notes 47-49 supra.

175. See 42 U.S.C. $\$ 4332$ (c) (1976).

176. See notes $50-60$ supra and accompanying text.

177. Federal control over navigation and navigable waters has been squarely within Congress' commerce clause power since Gibbons v. Ogden, 22 U.S. (9 Wheat.) 1, 83-84 (1824). The reach of the commerce power is now virtually limitless. See Katzenbach v. McClung, 379 U.S. 294 (1964); Heart of Atlanta Motel v. United States, 379 U.S. 241 (1964). But see National League of Cities v. Usery, 426 U.S. 833 (1976). Moreover, Congress has chosen to use this commerce power over navigable waters in a sweeping and comprehensive fashion, as exemplified in the 1972 Amendments to the Federal Water Pollution Control Act, Pub. L. No. 92-500, $\$ 8401-405,86$ Stat. 877 (codified at 33 U.S.C. $\$ \S 1251-1376$ (1976)). Section 402 of these amendinents provides for full federal control of water pollution in navigable waters. State pollution permit programs are limited to nonnavigable waters, which are not within federal control anyway, and to those waters that are navigable only because of historic use. 33 U.S.C. \& 1342 (1976). See note 35 supra. Finally, the Supreme Court in dictuin has stated that "It]here is no question that this [federal] power [to remove obstructions to navigable waters] is superior to that of the States to provide for the welfare or necessities of their inhabitants." Sanitary Dist. of Chicago v. United States, 266 U.S. 405, 426 (1925). But see Montgomery v. Portland, 190 U.S. 89 (1903); Cummings v. Chicago, 188 U.S. 410 (1903). 
waterway-related projects. This tactic has produced differing judicial views on the reach of the Corps' power over obstructions to navigable waters. While this process may achieve short-terin environmental victories, these interpretations threaten long-term environmental harun by destroying the Corps' statutory powers to conduct environmental reviews of certain projects. These differing views also hinder state agencies and urban planners who lack guidance as to the appropriate approval process to follow.

A congressional redrafting of these two sections would cure inany of these problems by including precisely divided approval powers and clarifying legislative intent. Under the redraft proposed in this Coininent, congressional approval would be required only for those extraordinary projects that would totally span the waterway and hinder present or future interstate or foreign commerce. State legislative approval power would be eliminated, since federal interests have becoine paramount and state concerns are sufficiently accommodated under normal environmental review. Finally, the Corps would have exclusive approval authority over obstructions to navigable waters not specifically enumerated in the current sections. This broad delegation of power to the Corps is necessary because of the difficulty of obtaiming congressional approval, the expertise of the Corps, the imappropriateness of state action, and the need for uniform environmental review.

David Lawrence Hankey 